\title{
Discussion of the Management Innovation of Student affairs in Academic Consultation System
}

\author{
Chaoyang Liu ${ }^{1,2}$, Fei Li ${ }^{1,2}$ a, ${ }^{\star}$, Maosheng $\mathrm{Liu}^{2}$ \\ ${ }^{1}$ Research Center for Environment and Health, Zhongnan University of Economics and Law, \\ Wuhan, China \\ ${ }^{2}$ School of Information and Safety Engineering, Zhongnan University of Economics and Law, \\ Wuhan, China \\ alifei@zuel.edu.cn
}

Corresponding authors: Fei Li

Keywords: Peking University, Academic Consultation, Student affairs Management, Innovation

\begin{abstract}
Public opinion holds different views on the academic consultation system of Peking University. However, from the perspective of student affairs management, following the management pattern and innovating management system boldly are desired to affirmative. To integrate school resources through academic consultation can solve students' practical issues more effectively while relieve the work stress of Counselors. For radical thoughts, the public opinion discussed vehemently, could be revised as partial thoughts from the perspective of social moral values, which will be understood and accepted by our society, media, school and students more easily.
\end{abstract}

\section{Introduction}

Since Peking University released the notification that student academic consultation has been operated tentatively at the department of medicine and Yuanpei College, based on the checking job in individual students, in the form of consultation, the university has deeply analyzed and scientifically judged the academic performance of the individual students with various powers, and has formulated and implemented effective support plan, meanwhile carried out one-on-one tutoring work deeply to help the individual students achieve an all-around and healthy development [1]. Peking University has given a clear definition of the individual students: focus on the students with academic problem and give consideration to other individual students with academic problem, radical thoughts, psychological fragility, economic poverty, school register change, independent living, internet addiction, employment problem, suffering from serious illness or receiving punishment of discipline violation.

The news has triggered uproar among the public, people have different opinions and unable to decide which is right. Some commenters point out that classify the students into ten categories is conductive to college students work management, breaks through existing passive management and single situation actively, integrates school mental health counseling center, employment guidance center, student financial assistance center and other functional departments of various resources, makes the school work from discovery to solve problems in the process of a series of active and effective support work. However, there are media pointed out those students due to the economic poverty, sickness and other reasons from the school's close attention besides strong questioning on radical thoughts. Due to the qualitative fuzzy, this standard is easily in conflict with all-embracing philosophy and ideological freedom which are the proud traditions of Peking University.

Aside radical thoughts the heart of the debate, simply analyze the academic consultation system from the perspective of college ideological and political education and student affairs management, I think it has two innovations: 


\section{Established "student-centered" conception.}

The implementation of this system is to envisage the issues and bottlenecks in student management, is an important channel to seek a series of prominent problems of students actively and a new innovative student management style which could trace history, prevent ahead and take the initiative to attack.

As everyone knows that a new departure of education and management focus on students has faced with triple pressure from school, students and society. Academic consultation is carried out in the background of social and economic rapid development, social transformation and the enrollment expansion of colleges. Nowadays, the post-90s college students are diversified with individual character. Their personal environment, educational situation and cognition degree of society are different. They receive a wide range of information with broad horizons. They have strong autonomy and independence but lack of beliefs [2]. Some college students pursue materialistic blindly, lose life faith and wallow in the network. They are cynical and muddleheaded. More worrisome, some students has become the specially privilege person after entering the college, and they don't understand tolerance and gratitude, lacking of diligent and economy because of the rich life. They are too ego, loose and luxury, indifferent to other person, and lack of common responsibility and moral sense. The junior student Yao Jiaxin proceeded to stab the wounded 6 times after he has hit her by car, which is a typical case. If the college is just a research establishment rather than an education center, the talents graduate from it don't have much blood of morality, then it will be a big worry for society, country and future. For some tendentious questions appeared among students, to put forward the academic consultation is a university's social responsibility, is a pragmatic and preventive measure and one kind of positive posture to respond the requirements of the public.

To summarize the problem students, and then help them one to one, it is follow the principle of the student-oriented and student affairs law, found the problem, face the problem and then solve the problem. Compared with some colleges which hide the student management, it has already taken one big step to improve the system.

\section{Integration of the resources and emphasis on efficiency}

It is indicated clearly in the notice: reflect the basic requirement of educating people at school, it is led by student affairs and medicine education department, dominated by medicine department and Yuanpei College, and cooperated with coherent units. The academic consultation system involves each related professional departments, psychological health education and reference center, student careers guidance service center, student aid center, dormitory management center, youth research center and other functional departments.

Counselor often is the person who finds and solves problem in student affairs management. Meanwhile, the location of Counselor's role as political guide is changing with development of The Time, they began to realize the educational function by current political lesson, one to one or one to many talk, part-time teacher in charge of the class service things, counselling and other work methods [3]. In practical work, a Counselor often should face to two hundred, even three hundred and four hundred students, their work stress and the requirement of operational capability is self-evident. Academic consultation not only can make front-line counselors to classify the problem students effectively on the basis of investigation, but also can clear their work thinking. So as to change the passive situation in the past, and give full play to the advantages of the whole school worker team to solve the problem of problem students really with the efforts of all functional departments concerned. Therefore, to integrate school resources through academic consultation can solve students' practical issues more effectively while relieve the work stress of Counselors.

However, academic consultation is not perfect, and has some areas to be improved. Radical thoughts become a target of society and media undoubtedly among the numerous problems. The first question is that is radical thoughts good or bad? From the aspect of student development, it is bad. The word radical with a negative meaning obviously, has made the judgment. In a rational society, both radical thoughts and radical behavior are not worthwhile to promote. But the problem is that, to 
criticize the school because the price of mess's meals has increased two cents, does it belong to radical thoughts? Each public department has the duty to accept criticism and supervision, we couldn't define a student as a problem student just because a few words of complaint and criticism. This is a kind of opinionated and mechanical management method of student affairs.

The second question is that should radical thoughts be tolerated? Viewing from the attribute of college education, it should be tolerated. Since human being entered into the civilized society, thought of innocence is one of the most basic social ethics and order. In legal society, no country has thought crime. That is to say, all thoughts are innocent without action. So all the systems can only regulate people's behavior, which shouldn't regulate their thought. Correct thought need to be realized through other ways, such as education. A civilized and harmonious society should be subordinate to the majorities, respect for minorities and tolerant individuals.

Therefore, academic consultation system incorporates radical thoughts into the problem students' rank, which is worth discussing. To analyze from the perspective of student daily routine management, today's students are personalized, some of them demand perfection in everything and some of them always look at the bad side of everything. But if really incorporate these kinds of students into the system of problem students and treat them as an issue seriously and conscientiously, I think it will not only bring problem to the general teachers, but also cause student's conflict, has the opposite effect. However, there is a part of students who unreasonably criticize everything without aim and responsibility, it is proved that such kind of students is difficult to find the sense of identity to the society and lack of team spirit after graduated. Thus, radical thoughts could be revised as partial thoughts, to get rid of the interference of any political ideas and system concepts, and to work purely from the perspective of social moral values. In this way, it is easily for our society, media, school and student to understand and accept.

\section{Conclusion}

The contemporary college students take charge of the national responsibility, they need to learn the necessary knowledge to set up the correct life attitude, and forge their strong psychological quality. To create the collective emotion and combine the moral education with daily teaching. On the one hand, the educators should set up morality to educate people and cultivate people with morality. On the other hand, they should choose targeted one to one guidance and intervention method. In this respect, the academic consultation of Peking University has taken a bold and solid step in the student management innovation. If we can explore the rule of student development positively, and have the courage to innovate system and solve problem, our students could better adapt to the various environments of college and grow up faster.

\section{Acknowledgements}

This research was supported by Hubei College Student Affairs Research Institute (1718WT15); the Graduate Innovative Education Program of Zhongnan University of Economics and Law (2016J1410, 2016J1411).

\section{References}

[1]. Lingbing Zheng, Weimin Wang. The research on Academic Consultation System under the Concept of integration of teaching Reform [J]. Beijing Education (Higer Education), 2013(04):61-62.

[2]. Junru Li. Innovation Research on the Basic Level of College Student Affairs under Weibo System [J]. University Counselors, 2016(04):56-59.

[3]. Lizhong Wu, Yuxiang Wang. Discussion on the Innovation for Evaluation of Ideological and Political Education for College Students Based on Perspective of Social Work [J]. China Youth Study, 2016(07): 34-38. 